\title{
Technical efficiency of semi organic rice farming In Sleman Regency, Special Region of Yogyakarta
}

\author{
Eni Istiyanti ${ }^{1,}{ }^{*}$, Retno Wulandari ${ }^{1}$, and Indah Widowati $^{2}$ \\ ${ }^{1}$ Lecturer of Department of Agribusiness, Faculty of Agriculture, Universitas Muhammadiyah \\ Yogyakarta, Indonesia \\ ${ }^{2}$ Department of Agribusiness, Faculty of Agriculture, Universitas Pembangunan Nasional "Veteran" \\ Yogyakarta, Indonesia
}

\begin{abstract}
The transition from conventional to organic agriculture is semiorganic farming. This study aims to analyze the technical efficiency and the factors that affect the technical inefficiency of semi-organic rice farming. The research was conducted in Sleman Regency, Special Region of Yogyakarta which was selected purposively. The number of respondents was 100 farmers determined by the multistage random sampling method. The Cobb Douglass frontier production function was used to analyze the technical efficiency. The results showed that the production factors that had a positive effect on semi-organic rice production were manure, phonska fertilizer, family workforce and non-family workforce, while the urea fertilizer had a negative effect. Semi-organic rice farming in Sleman Regency is not technically efficient with an average technical efficiency coefficient of 0.518. The age of farmer and land status has a effect on the technical inefficiency of semi-organic rice farming. Semi-organic rice farmers in Sleman Regency should reduce the use of urea fertilizer because it has a negative effect on production.
\end{abstract}

\section{Introduction}

The availability of rice in Indonesia can be obtained through three agricultural systems, namely non-organic, organic, and semi-organic farming systems. Non-organic farming system or what is commonly called conventional is an agricultural system which in its production process uses chemicals [1]. The continuous use of chemical inputs in farming can lead to decreased soil fertility, decreased biodiversity and increased pest, disease and weed attacks. Another negative impact is the contamination of agricultural products by chemicals which will have a negative impact on human health [2]. Public awareness of the dangers of chemicals to health and the environment encourages the development of environmentally sound and sustainable agricultural systems. Organic farming systems can be an alternative to environmentally friendly and sustainable farming systems [3]. The environmental benefits obtained by the application of organic farming are that it is easier to

* Corresponding author: eniistiyanti@umy.ac.id 
cultivate the soil and does not cause environmental pollution. Improvement of soil and environment as a result of organic farming can achieve technical efficiency [4].

The development of organic rice in various regions in Indonesia takes a long time. Land used for organic rice cultivation needs special requirements and the process of moving from conventional to organic systems takes 1-3 years [5]. The change from non-organic (conventional) rice farming to organic rice requires a transition period called semi-organic rice farming. The application of semi-organic rice farming includes land cultivation by reducing the dose of chemicals and increasing the dose of organic fertilizer made from nature, killing pests and weeds using biological pesticides and killing diseases using more doses of natural ingredients than chemicals. Semi-organic rice farming is a form of implementation of a sustainable agricultural system that requires farmers to have different and better farming behavior, especially for environmental aspects so that farming can be carried out continuously [6]

The Special Region of Yogyakarta (DIY) is one of the provinces that has launched a program to increase food security through organic agricultural cultivation that focuses on organic rice commodities with the slogan "Go Organic". Sleman Regency is one of the regencies in DIY which is developing rice farming towards organic. The background of the development of organic rice farming is the declining productivity of rice farming land. Rice productivity in 2015 was $65.27 \mathrm{kw} / \mathrm{ha}$, in 2016 it was $61.58 \mathrm{ku} / \mathrm{ha}$ and in 2017 it was 57.36 $\mathrm{kw} / \mathrm{ha}$.[7]. The decrease in productivity indicates a decrease in the level of land fertility, one of which is caused by the excessive use of chemical fertilizers [8].

The demand for organic and semi-organic rice in Sleman Regency tends to increase and farmers have not been able to meet market demand. This situation is due to limited land for cultivation so that production is not maximized. In addition, the means of producing organic fertilizers and pesticides must also be made by the farmers themselves. Organic and semi-organic rice cultivation requires water management to be free from pesticides and chemical mixtures. The existence of these treatments causes the use of more labor [9].

Increasing organic and semi-organic rice production through increasing land area is not easy and takes a long time. Therefore, increasing rice production through efficiency is the right choice. Efficiency is classified into three, namely technical efficiency, allocative efficiency, and economic efficiency. Technical efficiency shows the relative ability of the farm to obtain a certain output by using a certain amount of input at a certain level of technology. Allocative efficiency shows the relative ability of the farm to use inputs to produce outputs at minimum cost conditions or maximum profits at a certain level of technology. Allocative efficiency can be obtained in technically efficient farming conditions.

This study examines the level of technical efficiency of each farmer in semi-organic rice farming, how many farmers are already efficient and the factors that affect inefficiency (inefficient). Studies that have been done on organic or semi-organic rice farming are related to organic rice production and income compared to non-organic ones, such as those conducted by [10] in Sambi District, Boyolali Regency, [11] in Perbaungan District, Serdang Bedagai and [12] Nepal. This study aims to determine the factors that affect production, the level of technical efficiency and the factors that influence the technical inefficiency of semi-organic rice farming in Sleman Regency, Special Region of Yogyakarta.

\section{Research Method}

The study was conducted in Sleman Regency which was selected purposively based on the consideration that Sleman is the main food barn in the Special Region of Yogyakarta which is able to produce 80 thousand to 100 thousand tons of rice and contributes 35 to 40 percent 
of rice. Sleman Regency has the largest paddy field land and the largest number of organic certified rice farmer groups [13]. A farmer group can have organic certification if it has been running its organic farming for more than 3 years.

The research sample was taken using the Multistage Sampling method. This method is used when members of the population are spread over a large area. Sampling using the Multistage Sampling method was carried out through the following stages: purposive selection of district samples namely Sayegan and Godean with the consideration that the two districts were developing rice farming towards organic. Sayegan and Godean districts have farmer groups whose members are semi-organic rice farmers, namely Manunggal Karsa, Sri Rejeki, Ngudi Makmur 2, Makmur Baru, Tegal Mulyo, Guyup Rukun, Dadi Makmur and Ngudi Rahayu farmer groups. The number of members from 8 farmer groups who are trying to grow semi-organic rice is 161 and 100 farmers are taken based on the simple random sampling method.

The types of data used in this research are primary data and secondary data. Primary data is data obtained directly from the source or firsthand through interviews with questionnaires. The primary data in this study include the identity of farmers, the use of production facilities and labor, prices, and production results. Secondary data is data obtained by documenting existing data in related agencies or institutions, including the Central Statistics Agency and UPT BP4 for the Regions of Godean and Seyegan Districts. The secondary data include data on members of farmer groups, production data, and data on regional conditions.

The technical efficiency of semi-organic rice farming was analyzed using the CobbDouglas Frontier production function as developed by [14]. The stochastic frontier production function has the Cobb-Douglass form which is transformed in a linear natural logarithm mathematically written as follows:

$$
\begin{aligned}
& \operatorname{LnY}=\operatorname{Ln} \alpha_{0}+\alpha_{1} \operatorname{LnX}_{1}+\alpha_{2} \operatorname{LnX}_{2}+\alpha_{3} \operatorname{LnX}_{3}+\alpha_{4} \operatorname{LnX}_{4}+\alpha_{5} \operatorname{LnX}_{5}+\alpha_{6} \operatorname{LnX}_{6}+\alpha_{7} \operatorname{LnX}_{7}+ \\
& \text { (vi-ui) }
\end{aligned}
$$

Description:

$\mathrm{Y} \quad=$ Result rice production $(\mathrm{kg})$

$\alpha_{0}=$ Constant

$\alpha_{1-7}=$ Coefficient

$\mathrm{X}_{1}=$ Land area $\left(\mathrm{m}^{2}\right)$

$\mathrm{X}_{2} \quad=$ Seeds $(\mathrm{kg})$

$\mathrm{X}_{3}=$ Manure $(\mathrm{kg})$

$\mathrm{X}_{4}=$ Urea Fertilizer $(\mathrm{kg})$

$\mathrm{X}_{5} \quad=$ Phonska Fertilizer $(\mathrm{kg})$

$\mathrm{X}_{6} \quad=$ Family workforce (work day)

$\mathrm{X}_{7}$ = Non-family workforce (work day)

vi $=$ Error (disturbance term)

ui $\quad=$ The inefficiency effect that appears

Technical efficiency is measured using the formula:

$$
\mathrm{TEi}=\underline{\mathrm{Yi}}=\mathrm{E}[\exp (-\mathrm{Ui} / \varepsilon \mathrm{i})]
$$

Description :

$\mathrm{TEi}=$ Farmer's technical efficiency $\mathrm{i}$, with values ranging from 0 to 1

$\mathrm{Yi}=$ Output produced by farmers to $\mathrm{i}$

$\mathrm{i}=1,2,3, \ldots .100$ 
The value of technical efficiency is between 0 until 1 . The efficiency value of farmers can be categorized as quite efficient if it is 0.7 and not efficient if it is $<0.7$ [15]. Variable $\mathrm{Ui}$ is a random variable that describes technical inefficiency in production related to internal factors. If the value of Ui is getting bigger, then the inefficiency of farming is also getting bigger. Factors that are thought to affect rice production inefficiency are farmer's age $\left(Z_{1}\right)$, and land status $\left(Z_{2}\right)$. Mathematically the distribution value of the inefficiency effect (Ui) can be written as follows:

$$
\mathrm{Ui}=\delta_{0}+\delta_{1} Z_{1}+\delta_{2} Z_{2}
$$

Description:

$$
\begin{array}{ll}
\text { where Ui } & =\text { value of technical inefficiency } \\
\delta_{0} & =\text { constant } \\
\delta_{1} \text { and } \delta_{2} & =\text { coefficient } \\
\mathrm{Z}_{1} & =\text { Farmer's age } \\
\mathrm{Z}_{2} & =\text { Land status }
\end{array}
$$

Testing of the factors that affect technical inefficiency partially uses the $t$ test with the hypothesis written as follows:

Ho $=$ bi $=0$ means that the internal factor of the i-th farmer does not affect the level of technical inefficiency of semi-organic rice farming.

$\mathrm{Ha}=\mathrm{bi}=0$ means that the internal factors of the $\mathrm{i}$-th farmer affect the level of technical inefficiency of semi-organic rice farming.

Decision-making:

If $\mathrm{t}$ count $>\mathrm{t}$ table; then Ho is rejected and $\mathrm{Ha}$ is accepted, meaning that the internal factors of the $\mathrm{i}$-th farmer affect the level of inefficiency of semi-organic rice farming

If $\mathrm{t}$ count $<\mathrm{t}$ table; then $\mathrm{Ho}$ is accepted and $\mathrm{Ha}$ is rejected, meaning that the internal factors of the i-th farmer have no effect on the level of inefficiency of semi-organic rice farming

\section{Results and Discussion}

\subsection{Semi-organic rice farmer profile}

The semi-organic rice farmers used as respondents are farmers who live in Godean and Sayegan Districts, Sleman Regency and are members of farmer groups. Based on age, semi-organic rice farmers are classified as old farmers with an average age of 60 years. The relatively old age of farmers does not prevent farmers from cultivating semi-organic rice. Work that is quite heavy, such as land processing, planting, and harvesting, will be assisted by workers outside the family. The condition of the age of semi-organic rice farmers in Sleman is older than the age of organic rice farmers in Bantul Regency [16] and Nepal [12]. The education level of the majority of semi-organic rice farmers (61\%) is Elementary School and Junior High School. This condition is no different from the education level of organic rice farmers in West Bandung Regency where the majority have elementary and junior high school education [6].

Farmers experience in farming on average 31 years, with a minimum experience of 2 years and a maximum of 70 years. This is a long time in which farmers have been very understanding, the right way to cultivate rice. This is in line with [17] that the length of farming affects farmers' skills in increasing production yields. Based on the land area, 50\% 
of the farmers cultivate semi-organic rice with a land area of less than $3,000 \mathrm{~m}^{2}$ and the average area of arable land is 3,506. The land cultivated does not only belong to the farmers, but most of them belong to other people who are rented or share the profit. The profit-sharing system that is widely used by farmers is that all production costs are borne by the cultivator, each land owner and cultivator gets a 50\% share of the results. The land used for semi-organic rice farming in Sleman Regency is narrower than in Sragen Regency, which is $4,600 \mathrm{~m}^{2}[18]$.

Table 1. Profile of semi-organic rice farmers in Sleman Regency

\begin{tabular}{|l|c|c|}
\hline \multicolumn{1}{|c|}{ Description } & Number (person) & Percentage (\%) \\
\hline Age (years) & & 15 \\
\hline $34-48$ & 15 & 46 \\
$49-63$ & 46 & 33 \\
$64-78$ & 33 & 6 \\
$79-93$ & 6 & 41 \\
\hline Education & 41 & 20 \\
\hline Elementary school & 20 & 37 \\
Junior high school & 37 & 2 \\
High school & 2 & \\
College & & 16 \\
\hline Farming Experience (years) & 16 & 23 \\
\hline $2-11$ & 23 & 14 \\
$12-21$ & 14 & 23 \\
$22-31$ & 23 & 10 \\
$32-41$ & 10 & 9 \\
$42-51$ & 9 & 5 \\
$52-61$ & 5 & \\
$62-71$ & & 17 \\
\hline Land Area (m) & 17 & 17 \\
\hline$<1,000$ & 17 & 17 \\
$1,000-1,999$ & 17 & 10 \\
$2,000-2,999$ & 10 & 11 \\
$3,000-3,999$ & 11 & 28 \\
$4,000-4,999$ & 28 & 31 \\
$>5,000$ & & 4 \\
\hline Land Status & 31 & 14 \\
\hline One's own & 4 & 1 \\
Rent & 43 & \\
Profit sharing & 8 & 36 \\
Own \& rent & 14 & \\
Own \& profit sharing & 1 & \\
Own, rent \& profit sharing & & \\
\hline
\end{tabular}

The production of semi-organic rice in Sleman Regency averages 1,161 kg for a land area of $3,506 \mathrm{~m}^{2}$ or 3.3 tons/ha of dry milled grain. This semi-organic rice production is lower than organic rice production in Boyolali Regency [19] and Maros Regency [20]. The seeds used by farmers include Ciherang, Mekongga, Logawa, Cianjur and IR 42 with an average use of $15 \mathrm{~kg}$. The average manure used by farmers is $370 \mathrm{~kg}$, which comes from cow and chicken manure. The use of manure is in the low category, because the dose of manure should be 2 tons/ha [19]. In addition to manure, semi-organic rice farmers still use chemical fertilizers, namely urea fertilizer with an average of $73 \mathrm{~kg}$ and Phonskha fertilizer of $43 \mathrm{~kg}$. The use of chemical fertilizers is $30 \%$ of the use of manure. The workers used by farmers are in the form of family workers with an average use of 19.78 work days and 7.37 work days non family workforce. 
Table 2. Production and level of use of production factors in semi-organic rice farming in Sleman Regency.

\begin{tabular}{|l|l|l|l|}
\hline Production/Factor of production & Average & Maximum value & Minimum value \\
\hline Production $(\mathrm{kg})$ & $1,161.12$ & 8,400 & 25 \\
\hline Land area $\left(\mathrm{m}^{2}\right)$ & 3,506 & 15,000 & 200 \\
\hline Seed $(\mathrm{kg})$ & 15 & 50 & 0.5 \\
\hline Manure $(\mathrm{kg})$ & 370 & 3,000 & 10 \\
\hline Urea fertilizer $(\mathrm{kg})$ & 73 & 300 & 0 \\
\hline Phonskha fertilizer $(\mathrm{kg})$ & 43 & 300 & 0 \\
\hline Family workforce (work day) & 19.78 & 97.19 & 1.5 \\
\hline Non family workforce (work day) & 7.37 & 34 & 1.6 \\
\hline
\end{tabular}

\subsection{Production Function}

The production function used in this study is a production function of cobb douglass frontier with the dependent variable being semi-organic rice production and the independent variables include land, seeds, manure, urea fertilizer, phonskha fertilizer, the family workforce and non-workforce.

The results of the analysis show that pin organic rice farming the MLE log likelihood value (- 73.303) is greater than the OLS log likelihood (-98.014), meaning that in semiorganic rice farming the production function with the MLE method is better and in accordance with the conditions in the field. Sigma-square value of semi-organic rice 1.174 shows that the term error of semi-organic rice inefficiency is not normally distributed [15]. The gamma value for organic rice 0.999 is statistically different from null which means that the variation in production in semi-organic rice farming occurs due to inefficiency factors. In semi-organic rice farming in Sleman Regency, the production factors that have a significantly positive effect are manure, phonskha fertilizer, the family workforce and nonfamily workforce, while the significant negative effect is urea fertilizer. Land and seed production factors have no significant effect.

Table 3. Factors affecting to the production of semi-organic rice in Sleman Regency

\begin{tabular}{|l|r|r|}
\hline \multicolumn{1}{|c|}{ Variable } & Coefficient & \multicolumn{1}{c|}{ T-value } \\
\hline Constant & $2.977^{*}$ & 1.290 \\
\hline Land area & $0.173^{\text {ns }}$ & 0.422 \\
\hline Seed & $-0.052^{\text {ns }}$ & -0.144 \\
\hline Manure & $0.072^{*}$ & 1.363 \\
\hline Urea fertilizer & $-0.090^{* * *}$ & -5.090 \\
\hline Phonska fertilizer & $0.045^{* *}$ & 1.680 \\
\hline Family workforce & $0.852^{* * *}$ & 5.604 \\
\hline Non-family workforce & $0.401^{* * *}$ & 2.494 \\
\hline Sigma square & 1.174 & 3.465 \\
\hline Gamma & 0.999 & $1,619.142$ \\
\hline
\end{tabular}

Description: $\mathrm{ns}=$ non-significant

* = significant at $10 \%$

$* *$ = significant at $5 \%$

$* * *=$ significant at $1 \%$

The land production factor has a regression coefficient of 0.173 and has no significant effect, meaning that if land use is added and other factors remain, there is a tendency for semi-organic rice production to increase. The same situation also occurs in Vietnam, where land does not significantly affect rice production [21], while in organic rice farming in 
Lampung province, land has a significant effect [22]. It is possible to add land by replacing non-organic rice plants with semi-organic or organic ones. The number of organic or semiorganic rice farmers in Sleman Regency is only around 10\% [23] and most of the farmers still grow non-organic rice.

The seed regression coefficient is -0.052 and is not significant, meaning that if the use of seeds is added and other factors remain, there is a tendency to reduce semi-organic rice production. Different things happen to organic rice farming in Nigeria, where seeds have a significant effect on rice production [24]. Semi-organic rice farmers in Sleman use a spacing of $20 \times 20 \mathrm{~cm}$ and is the standard spacing. If the use of seeds is added it will inhibit growth and development because it is too tight.

The manure production factor has a regression coefficient of 0.072 and is significant, meaning that if the use of manure is added by $1 \%$ and other factors remain, the semiorganic rice production will increase by $0.072 \%$. Manure is a staple fertilizer in semiorganic and organic rice farming because it contains elements of $\mathrm{N}, \mathrm{P}, \mathrm{K}$ and $\mathrm{C}$ with a ratio between $\mathrm{C}$ and $\mathrm{N}$ of about $40 \%$ which is needed by rice plants [25], besides that, manure also serves to improve the properties of physics, chemistry and soil biology [26]. The right use of manure on rice plants can increase production as according to [27] applying 5 tons/ha of manure to rice plants can increase dry grain yields by $10 \%$.

The regression coefficient for urea fertilizer is -0.090 and is significant, which can be interpreted if the use of urea fertilizer is added by $1 \%$ and other factors remain, the rice production will decrease by $0.090 \%$. Urea fertilizer is a chemical fertilizer containing the element $\mathrm{N}$ which is needed for the growth of rice plants. The application of urea fertilizer can increase plant height, number of tillers and production of rice plants [28].

Phonskha fertilizer has a regression coefficient of 0.045 and is significant, it can be interpreted that if the use of Phonskha fertilizer is added by $1 \%$ and other factors remain, the production of semi-organic rice will increase by $0.045 \%$. Phonskha fertilizer is a compound chemical fertilizer containing N, P and K elements. Phonska fertilizer application will increase the availability of NPK elements in a fairly balanced amount, to meet plant needs for these nutrients, and result in increased dry grain production. in real terms [29].

The regression coefficient of labor in the family is 0.852 and it is significant that if the workforce in the family is increased by $1 \%$ and other factors remain, the semi-organic rice production will increase by $0.852 \%$. Non family workforce have a regression coefficient of 0.401 and have a significant effect on semi-organic rice production, meaning that if nonfamily workforce are increased by $1 \%$ with other factors remaining, semi-organic rice production will increase by $0.401 \%$. This shows that workers outside the family are processing land, planting and harvesting. This situation is similar to [18] on organic rice farming in Sragen, labor has a significant effect on production with a positive regression coefficient.

\subsection{Technical efficiency}

Based on production function analysis stochastic frontier the level of technical efficiency can be known. Farming is said to be efficient if the technical efficiency index value is greater than 0.7 [14]. The average value of the technical efficiency index of semi-organic rice farming in Sleman Regency is 0.518 , which means it is not efficient. As many as $25 \%$ of farmers have actually been efficient in farming, but $75 \%$ of farmers have not been efficient. 
Table 4. The distribution of technical efficiency level of semi-organic rice farming in Sleman Regency

\begin{tabular}{|l|r|r|}
\hline \multicolumn{1}{|c|}{ Category } & Amount (person) & Percentage (\%) \\
\hline $0.000-0.100$ & 0 & 0 \\
\hline $0.101-0.200$ & 6 & 6 \\
\hline $0.201-0.300$ & 17 & 17 \\
\hline $0.301-0.400$ & 11 & 11 \\
\hline $0.401-0.500$ & 10 & 10 \\
\hline $0.501-0.600$ & 16 & 16 \\
\hline $0.601-0.700$ & 15 & 15 \\
\hline $0.701-0.800$ & 7 & 7 \\
\hline $0.801-0.900$ & 6 & 6 \\
\hline $0.901-1,000$ & 12 & 12 \\
\hline Mean Technical Efficiency & 0.518 & \\
\hline Total Respondents & 100.00 & \\
\hline Minimum value & 0.115 & \\
\hline Maximum value & 0.997 & \\
\hline
\end{tabular}

The technical efficiency index value of semi-organic rice farming in Sleman is lower than that of organic rice farming in Sragen Regency, namely 0.7 [18], lower than organic rice farming in Tasikmalaya Regency of 0.86 [30], more smaller than lowland rice farming in the Integrated Crop Management program in Riau Regency is 0.87 [31] and more smaller than rice farming in rainfed lawland in Maros Regency [20].

Semi-organic rice farmers in Sleman Regency still use chemical fertilizers, namely urea and NPK phonska fertilizers in large quantities, that are $30 \%$ of the use of organic fertilizer (manure). Farmers use urea and phonska fertilizers with the aim that the availability of chemical elements $\mathrm{N}, \mathrm{P}$ and $\mathrm{K}$ in the soil is balanced so that plant growth is optimal, increasing the number of tillers and rice production [29].

The analysis uses the stochastic frontier production function in addition to knowing the level of efficiency; it can also determine the factors that affect inefficiency. In semi-organic rice farming the variables of farmer's age and land status are included in the model, and all factors have a significant effect on technical inefficiency.

Table 5. Factors contributing to semi-organic rice technical inefficiency

\begin{tabular}{|l|c|c|}
\hline \multicolumn{1}{|c|}{ Variable } & \multicolumn{2}{|c|}{ Organic rice } \\
\hline Constant & Coefficient & T-value \\
\hline Farmer's a,ge & 0.707 & 0.567 \\
\hline Land status & $-0.185^{* * *}$ & -2.321 \\
\hline
\end{tabular}

Description: $\mathrm{ns}=$ non-significant

$* * *=$ significant at $=1 \%$

$* *$ significant at $=5 \%$

The farmer age variable has a coefficient of -0.185 and is significant, meaning that the older the farmer, the lower the level of inefficiency in semi-organic rice farming, in other words, the more efficient the farm. As many as $25 \%$ of farmers who have been efficient, the majority (more than $80 \%$ ) are over 55 years old. The older the farmer, the more experience in farming, so that he can determine the most profitable cultivation methods. This situation is in line with research [32] in Bantul Regency and [24] in Nigeria where age has a negative effect on the inefficiency coefficient, but it is different from the results of [33] in Indonesia where age has a positive coefficient.

Land status has a coefficient of -0.518 and is significant, it can be interpreted that the status of owned land can reduce level of technical inefficiency, in other words, farmers with 
own land status are more efficient than land rent status or profit sharing. Farmers who work on their own land are $32 \%$ and those who use land rent or profit sharing are $68 \%$. This is in line with the research of [33] where land status affects technical inefficiency with a negative coefficient.

\section{Conclusions and Suggestions}

Factors that have a positive effect on semi-organic rice production in Sleman Regency are manure, phonskha fertilizer, family workforce and non-family workforce, while the factor that has a negative influence is urea fertilizer. Semi-organic rice farming has not been technically efficient with an average efficiency index of 0.518 . Farmer age and land status are factors affecting the technical inefficiency of semi-organic rice farming.

Semi-organic rice farmers in Sleman Regency should reduce the use of urea fertilizer because it has a negative effect on production. Farmers can replace urea fertilizer with manure which is cheaper and easier to obtain.

Acknowledgment. The writers would like to express gratitude to the Publication, Research and Community Service Institute (LP3M) of Universitas Muhammadiyah Yogyakarta for providing funds for this research. Likewise with college of Agribusiness department of Universitas Muhammadiyah Yogyakarta and Universitas Pembangunan Nasional "Veteran" Yogyakarta who support and facilitate so than the research can be done.

\section{References}

1. S. E. D. Aryanti, N.A, Windiana, L., Agroveteriner 6, 62 (2017).

2. H. Mayrowani, Forum Penelit. Agro Ekon. 30, 91 (2016).

3. M. Vassalos, C. R. Dillon, and P. Karanikolas, in Role Knowledge, Innov. Hum. Cap. Multifuncional Agric. Rural Dev. (Belgrade, Republic of Serbia, 2009).

4. T. M. Prihtanti, S. Hardyastuti, S. Hartono, and Irham, J. AGRIFOR XII, 11 (2013).

5. Y. Surdianto and N. Sutrisna, Petunjuk Teknis Budidaya Padi Organik, Pertama (BPTP Jawa Barat, Bandung, 2015).

6. A. Charina, R. Andriani, B. Kusumo, A. H. Sadeli, and Y. Deliana, 14, (2018).

7. Badan Pusat Statistik, Kabupaten Sleman Dalam Angka 2019 (Badan Pusat Statistik, 2019).

8. D. U. Siswanti, J. Pengabdi. Kpd. Masy. (Indonesian J. Community Engag. 1, 62 (2015).

9. F. Shiotsu, N. Sakagami, N. Asagi, D. N. Suprapta, N. Agustiani, Y. Nitta, and M. Komatsuzaki, Sustain. 7, 5171 (2015).

10. M. S. Andalas and Sudrajat., Bumi Indones. 7, 1 (2018).

11. S. V. Br. Butar-butar, Salmiah, and M. Roem, J. Soc. Econ. Agric. Agribus. 4, 1 (2015).

12. R. K. Adhikari, J. Agric. Environ. 12, 97 (2011).

13. Badan Pusat Statistik, Luas Lahan Pertanian Dan Bukan Pertanian Menurut Kabupaten/Kota Di D.I. Yogyakart (Yogyakarta, 2016).

14. T. Coelli, D. S. P. Rao, and G. E. Battese, An Introduction to Efficiency and Productivity Analysis. (Kluwer Academic Analysis., Boston, 1989). 
15. L. Gultom, R. Winandi, and S. Jahroh, J. Inform. Pertan. XXIII, 7 (2014).

16. N. Rahmawati and T. Triyono, Agrar. J. Agribus. Rural Dev. Res. 3, (2017).

17. N. Sandiani, Agrotekbis 2, 199 (2014).

18. A. Prayoga, Agro Econ. J. 28, 1 (2010).

19. P. Permatasari, S. Anantanyu, and W. S. Dewi, Caraka Tani J. Sustain. Agric. 33, 153 (2018).

20. Arifin, A. A. Wahditiya, Nirawati, and M. A. Biba, Int. J. Sci. Technol. Res. 7, 52 (2018).

21. V. H. Linh, Int. J. Dev. Issues 11, 60 (2012).

22. K. Murniati, J. H. Mulyo, Irham, and S. Hartono, J. Penelit. Pertan. Terap. 14, 31 (2014)

23. Departemen Pertanian DIY, Statistik Tanaman Pangan (Badan Pusat Statistik, Daerah Istimewa Togyakarta, 2017).

24. F. A. . Kadiri, C. C. Eze, J. S. Orebiyi, J. I. Lemchi, D. O. Ohajianya, and I. U. Nwaiwu, Agric. Res. 2, 33 (2014).

25. A. Atman, J. Sains Agro 5, (2020).

26. R. Prasetyo, Planta Trop. J. Agro Sci. 2, 125 (2014).

27. G. R. Pratiwi and Sumarno, Penelit. Pertan. Tanam. Pangan 33, 177 (2014).

28. R. Anhar, E. Hayati, M. Agroteknologi, F. Pertanian, U. Syiah, D. Agroteknologi, F. Pertanian, U. Syiah, and D. B. Aceh, J. Kawista Agroteknologi 1, 30 (2016).

29. R. N. Ratna Shanti, J. Agroekoteknologi Trop. Lembab 3, 19 (2020).

30. N. Machmuddin, N. Kusnadi, and Syaukat, Forum Agribisnis 6, 145 (2016).

31. H. Bahasoan, J. Agribisnis 7, 211 (2013).

32. E. Istiyanti, L. Rahayu, and Sriyadi, Int. Food Res. J. 25, 173 (2018).

33. N. Kusnadi, N. Tinaprilla, S. H. Susilowati, and A. Purwoto, J. Agro Ekon. 29, 25 (2011). 